\title{
Śmierć w badaniach biograficznych
}

Streszczenie: Artykuł jest krytyczną analizą literatury obcej w poszukiwaniu prac poświęconych śmierci. Omówiono w nim prace Vincenta Humbert - Je vous demande le droit de mourir oraz Jean-Dominique Bauby - Skafander i motyl. Szczególne miejsce w artykule zajmuje książka Histoire de morts au cours la vie wydana pod redakcją M. Lani-Bayle, a poświęcona badaniom biograficznym nad zjawiskiem śmierci i przygotowania się do śmierci własnej i najbliższych.

Słowa kluczowe: biografia, śmierć, trauma.

\section{Death in biographical research}

Summary: This article presents a critical review of foreign literature about death. The author discussed of Vincent Humbert's - Je vous demande le droit de mourir and Jean-Dominique Bauby's - Skafander i motyl works. The book Histoire de morts au cours la vie edited by M. Lani-Bayle assume a special place in this paper and it is devoted to the biographical research over death phenomenon and preparation for own and relatives death.

Keywords: biography, death, trau.

Opracowanie to jest relacją z lektury i własnych przemyśleń związanych ze śmiercią. Śmierć jest najtrudniejszym problemem obok choroby i bólu. Stanowi granicę, barierę, jest tajemnicą, można ją porównać do ciężkiej kurtyny, która zapada i nie podnosi się nigdy. Co za kurtyną, można jedynie domyślać się, mniemać, przypuszczać. Człowiek współczesny kryje się przed śmiercią. Nie chce do-

* Akademia Humanistyczno-Ekonomiczna w Łodzi, 90-212 Łódź ul. Sterlinga 26, emerytowany prof. UŁ. 
puszczać myśli o jej realności. Memento Mori dziś nie funkcjonuje, jest spychane w niepamięć. Śmierć, a raczej to w co wierzy się, że nas spotka po śmierci było i jest tajemnicą. Współczesna kultura oddala śmierć od nas. Umiera się daleko, w szpitalu, w hospicjum, w domu opieki, w otoczeniu obcych ludzi, za parawanem, za zasłoną, pod opieką specjalistów, nie rodziny. Nie myśli się o śmierci, jeśli się dopuszcza myśli to najczęściej dotyczą testamentu, miejsca pochówku, pogrzebu. Tak zrobiła Wisława Szymborska, pozostawiając testament i dokładne wskazówki dotyczące spuścizny literackiej i majątkowej.

Śmierć może być także pragnieniem, oczekiwanym przejściem do lepszego życia, do zbliżenia z Bogiem. Tak jest w przypadku mistyczek i mistyków. O śmierci marzyli: św. Teresa z Avila i św. Teresa z Lisieux, św. Franciszek z Asyżu, św. Ryta, św. Róża z Limy i wielu innych świętych. Św. Franciszek nazywał śmierć siostrą. Św. Teresa z Avila woła:

\footnotetext{
Widzisz tu serce moje, i Życie od zarania, Składam je w ręce Twoje! i Wszystkie me kochania. I wszystkie władze duszy, by miłość je objęła... Daj mi śmierć albo życie, daj siły czy słabość...
}

Książkę poświęconą śmierci w badaniach biograficznych otwiera przedmowa Edgara Morina pt. Śmierć żyjących. Pisarz ten jest autorem książki Człowiek $i$ śmierć (L’homme et la mort), która ukazała się w $1981 \mathrm{r}$. i jest traktowana jako klasyczna. Autor analizuje proces śmierci i odraczania się do życia. Coś umiera i coś się ożywia, ale następuje kres tego procesu i już nic nie odracza się, wszystko obumiera.

Morin odtwarza swoje wspomnienia śmierci osób bliskich. Zaczyna od momentu urodzenia się. Jego matka chorowała na grypę hiszpańską. Przeżyła grypę, ale zapadła na zdrowiu, na serce. Odradzano jej ciąże i porody, lekarze uważali, że może to zagrażać jej życiu. Poród był ciężki, znajdowała się na granicy życia i śmierci. Morin urodził się z trudem, był niedotleniony. Lekarze długo pobudzali go do życia. Udało się, wywołano oddech i pierwszy krzyk. Ten moment Morin pamięta, przynajmniej tak mu się zawsze wydawało. Był to w jego świadomości pierwszy próg śmierci. Zapamiętał śmierć swojej matki, a potem innych bliskich osób, ciotek, ojca i swojej trzeciej żony Jadwigi. Pamięć śmierci przyjaciół w okresie okupacji Francji w kazamatach gestapo. Śmierć wymaga spokoju, rytuału, ceremonii, spokoju i czułości. Jeśli przedmowę E. Morin potraktować jako wskazania dotyczące badań biograficznych, to zawiera dwie wskazówki, jedna dotyczy pamięci dzieciństwa, druga pamięci śmierci najbliższych. Pamięć dzieciństwa, prowadziłam takie badania. Jedna ze studentek pisząca pracę magisterską na temat dzieciństwa stwierdziła, że pamięta moment swojego przyjścia na świat i opowiadała o pokoju, w którym się urodziła i pierwszych chwilach swego życia. Matka potwierdziła prawdziwość jej opowiadania. Prawie każdy z nas nosi 
wspomnienia śmierci swoich bliskich lub przyjaciół. Pamiętamy pogrzeby i „stypy", ostatnie rozmowy.

Dalszy ciąg książki to wprowadzenie Gastona Pineau pt. Czas umierania $w$ trzeciej, w drugiej i pierwszej osobie, śmierć i narodziny są elementami edukacji permanentnej, od kolebki aż po grób. Badania biograficzne koncentrują się wokół procesu edukacji, ważnych wydarzeń życiowych. Przeżywanie śmierci bliskich otwiera przed nami różne przestrzenie, przeżycia dramatyczne, raniące nas, tworzą ranę, która się otwiera. Śmierć w trakcie biegu życia przychodzi pod różną postacią i formą. Inaczej powstaje doświadczenie śmierci, gdy towarzyszymy umierającym. To świadectwo wolontariuszki Marie Ihe'Laclaverie (2008) czy autobiografia chorej na raka Michele Pelotier (2007).

W 2007 r. odbyło się w Tours międzynarodowe kolokwium. Materiały zgromadzone w trakcie badań pozwalają stwierdzić co następuje: Śmierć jest częścią życia i musi występować w biografiach. Biografia, która nie prowadzi aż do śmierci jest cząstkowa, nieprawdziwa, zatrzymuje się na faktach i przeżyciach, jest nastawiona na odbiór, na publiczność, nie zawiera rzeczywistych przeżyć, prawdziwych doznań.

Uczenie się śmierci i umierania przebiega w następujących przestrzeniach:

- przestrzeń pierwsza, społeczna zawiera wiedzę o obyczajach i zwyczajach, o rytuałach towarzyszących śmierci w społeczeństwie,

- przestrzeń druga to umiejętne towarzyszenie umierającym bliskim i kontakt z nimi w ciężkiej chorobie i w sytuacji agonii,

- przestrzeń trzecia to przygotowanie się do własnej śmierci.

Te trzy dziedziny przygotowania się do śmierci odnaleźć można w narracjach, wspomnieniach, w literaturze biograficznej. Uczenie się śmierci zastygło w osłupieniu w okresie II wojny światowej, w sytuacji obozów zagłady, mordów narodów Żydów, Cyganów, w sytuacji nalotów, aresztowań, tortur, głodu, klęsk żywiołowych, zamachów i tym podobne. W pieśni pokutnej, błagalnej: Wielki Boże, Wielki a Nieśmiertelny błagamy Cię Panie - śpiewamy - od głodu, wojny i nagłej i niespodziewanej śmierci wybaw nas Panie.

Od książki E. Morina, wydanej w 1951 r., i innych prac poświęconych śmierci dużo się zmieniło. Śmierć oddaliła się od rodziny, od zachowania tradycyjnych rytuałów, uległa przekształceniom obcej kultury. Pojawia się obraz nirwany w tradycji buddyjskiej. Pozostała jednak dalej tajemnica przejścia do innego życia, do jakiego życia, przejścia z życia do życia. Śmierć pozostaje tajemnicą i częścią życia każdej istoty, która się narodziła.

Społeczeństwo postmodernistyczne ucieka przed rozważaniami o śmierci, przed przygotowaniem się do śmierci i umierania. Śmierć może wkraczać w nasze życie za pośrednictwem pracy, którą wykonujemy. Do zawodów graniczących ze śmiercią należy zawód lekarza, pielęgniarki, osób opiekujących się ciężko chorymi, osobami w sytuacji agonalnej, chronicznie chorymi, osób pracujących w hospicjach, instytucjach wspierających osoby ciężko chore. 
Instytucje te dbają o pacjenta, aby ostatnie dni jego życia przeżywał bez bólu i strachu, był spokojny, cieszył się każdym dniem i nocą. Ich rolą jest zniwelowanie bólu i ograniczenie strachu przed śmiercią. Ważną rolę w tych instytucjach wypełniają kapelani służący posługą tym wszystkim, którzy tego pragną i na co oczekują, chcą pojednać się z Bogiem i ludźmi, chcą wejść w drugie życie spokojnie bez lęku z miłością i ufnością. Obok służb oferowanych przez instytucje religijne powstały służby i instytucje opiekujące się osobami chorymi śmiertelnie.

Michel Fontanie - dominikanin, specjalista w zakresie pomocy chronicznie chorym w sytuacji agonalnej, duszpasterz w szpitalach i hospicjach w Szwajcarii i Afryce, pracując w Kamerunie, starał się poznać stosunek do śmierci i umierania w Afryce. Badał rytuały, stosunek do ciężko chorych i umierających, obrzędy pogrzebowe, sposoby pomocy i opieki nad osobami chorymi.

Według tego autora funkcjonują dwie wizje śmierci - jako kary, odrzucenia i bliska ujęciu judeo-chrześcijańskiemu - końca, przejścia do nowego życia. Jedyną drogą pomocy jest działanie zmierzające do opanowania bólu i strachu, pomoc w przekraczaniu progu śmierci.

W podobnym tonie pisze Caroline Galbe. Przedstawia ona początki kształcenia służb wspierających osoby w stanie agonalnym, termalnym, pisze o funkcjonujących w Tours i Anders od 2002 r. studiach. Przypomina działające od 1989 r. stowarzyszenie opieki paliatywnej SEAP i służby w Szpitalu Hôtel-Dieu, najstarszym szpitalu Paryża. Przypomina działania Cecily Saunders w Londynie i Therese Vanihier we Francji. Opieka paliatywna od łacińskiego palliare i greckiego pallium - płaszcza okrywającego zwłoki umierającego. Płaszcz ma chronić przed zimnem, deszczem, przed strachem i bólem. Program studiów przedstawia różne rytuały śmierci, pogrzebu, różne wierzenia i formy wsparcia umierających.

Kolejny tekst jest kontynuacją dwóch poprzednich, Nicole Croyére, pracownica paryskiej sieci służb paliatywnych, podaje przykłady rozmów z chorymi na raka. Daje wskazówki, jak dobierać słowa, informować o chorobie. Stwierdza, że nie ma wskazań ogólnych, choć jest ogólne przygotowanie, to trzeba uczyć się przygotowania do śmierci każdej osoby z osobna. Bycie obecnym, bycie do dyspozycji, bycie dostępnym, skoncentrowanym na osobie, jej doświadczeniach rodzinnych, wartościach, potrzebach.

Życie ma wartość nawet w chwili choroby, bólu i śmierci, jest ciągłością. Życie ma sens, to że jest życiem, chwilą, świadomością.

Kolejny tekst napisała osoba zajmująca się zawodowo badaniami biograficznymi, tytuł tego tekstu jest następujący: Trauma w historii życia. Życie może toczyć się spokojnie, bez nieprzewidzianych wydarzeń, nie myślimy o śmierci, o chorobie, o nieszczęściach, ale gdy przeżyjemy śmierć osoby bliskiej, myślimy już o śmierci w odniesieniu do nas. Autorka przypomina sobie traumę, przerażenie, gdy po porodzie jej matka ciężko zachorowała. Przeżyła, choć nie było to zanotowane w jej pamięci. Trauma, szpitale, dziecko bez matki. Różne doświadczenia śmierci i choroby też wymienione z oglądania obrazu Rembrandta - lekcja 
anatomii doktora Tulip. Śmierć uosobiona przez zwłoki innej osoby. Freud uważa, że człowiek nie potrafi sobie wyobrazić własnej śmierci bo już nie będzie wtedy osobą.

Trauma, według Autorki, jest przeżyciem bardzo głębokim, wstrząsającym, wywołanym jakimś wydarzeniem, wstrząsem, przeżyciem. Jeśli przedstawiamy życie jako ciągłość, jako linię, to na owej linii pojawiają się wydarzenia szczęśliwe, radosne i smutne, trudne, bolesne, traumatyczne. Śmierć bliskich powoduje właśnie owe traumatyczne przeżycia. Autorka analizuje wywiady biograficzne - przeżycia chłopca, który łowił ryby i wszedł do wody, w pewnym momencie poziom wody podniósł się i chłopiec zaczął tonąć, przestraszył się i wołał o pomoc, ale gdy wydostał się z rzeki, strach minął. Podobne przeżycia śmierci przez tonięcie opisał żołnierz z I wojny światowej. Przeżycie traumy zawiera wywiad 25-letniej Matyldy, wolontariuszki, która zabezpieczywszy się przez zastrzyki wyruszyła na misję do Afryki. Podróż i pobyt przeżyła jako wydarzenia znaczące i ciekawe. Po powrocie zachorowała, znalazła się w szpitalu. Stwierdzono, że ma malarię. Choroba okazała się bardzo ciężka. Matylda doznała traumy, bała się, że umrze. Ale powoli zaczęła czuć się lepiej. Trauma przeminęła i myśli o śmierci zniknęły.

Wyjątkowe przeżycia zawiera praca opublikowana przez Vincenta Humberta (2002) Je vous demande le droit de mourir. Sparaliżowany po wypadku kciukiem pisał swoją opowieść. Drugą osobą jest Jean-Dominique Bauby, autor książki Skafander i motyl (1997), który mrugając okiem, dyktował swoją opowieść, świadectwo przeżyć. Opowieść toczy się tu i teraz, jest stanem świadomości bez przeszłości i bez przyszłości. Trzeba uczyć się teraźniejszości chwilą, doznaniem. Bauby chce umrzeć, bo ta chwila i obecne życie jest trudne, koszmarne, traci się samodzielność, intymność, ale się trwa i doznaje różnych stanów, ogląda się zachody i wschody słońca, dzień i noc. Książki dyktowane przez obu sparaliżowanych młodych ludzi są prawdziwymi hymnami życia. Odzyskiwaniem poczucia tożsamości, sposobami wyrażania uczuć, przeżyć, przemyśleń, twórczym trwaniem w pozbawionej samodzielności egzystencji, przeciwstawianiem świata życia światu śmierci.

Patrick Brun - w towarzyszeniu chorym na HIV medycyna znajdowała różne lekarstwa, przedłużała czas życia. Powstał cały rytuał choroby i leczenia - terminy wizyt, analiz krwi, nowych terapii, przedłużania okresu życia z roku na dwa lata, trzy, cztery lata, pięć lat, towarzyszenie rozwojowi choroby i jej etapom, pogarszającemu się stanowi zdrowia, niemocy, umierania. Przyjaciel umarł w dzień Zesłania Ducha Św., w Zielone Świątki.

Ważny tekst stanowią Noce agonii G. Pineau. Agonia jest końcem życia, ale jeszcze życiem. Jest ostatnią podróżą. W społeczeństwie postmodernistycznym w proces agonii wkracza eutanazja, samobójstwo, nagła śmierć przez wypadki, katastrofy. Stan przed śmiercią, z którego się powraca do życia, można porównać do snu w nocy, po którym następuje przebudzenie, powrót do życia. Pozostają sny 
przejścia światła, tunelu, drogi. Noc może być porównywana do śmierci, ale jest pewna trudność w zaśnięciu, bezsenność, myśli przeszłości i przyszłości „mieszania" się czasu nocy z czasem dnia.

Platon świadome łączył życie z jasnością, ze słońcem, ze stanem pełnej świadomości. Św. Jan od Krzyża pisał o nocy duszy, o ciemności w odczuwaniu obecności Boga, łączności z Bogiem. Noc Duszy. Noc w naszej kulturze ma konotacje negatywne. Rodzi lęk, traumę, że się nie obudzimy, nie powróci nam świadomość, zdolność do życia.

Kontynuacją rozważań G. Pineau jest tekst mnicha buddyjskiego opisujący jego wypadek, jaki miał, jadąc motocyklem po drodze w górach. Nagle uderzył w balustradę. Spadł z motoru i upadł. Zatrzymały się dwa samochody, wezwano pomoc. Stracił przytomność i przebywał w przestrzeni chmur. Gdy odzyskał przytomność, pytał się, ile czasu trwała pomoc strażaków. Powiedziano mu, że 20 minut, zdawało mu się, że dłużej. Odzyskał pamięć i przytomność. Gdy opowiadał o swoich przeżyciach, uważano, że jest stuknięty, nawiedzony jak pies dingo.

M. Lani-Bayle zamieściła w książce tekst bardzo osobisty. Wspomnienie towarzyszenia śmierci swoich rodziców, Ojcu i Matce. Stan agonalny matki był szczególnie dramatyczny. Nie mogę go przedstawić, czytam ten tekst $\mathrm{z}$ wielkim trudem i emocją. Na marginesie tekstu umieszczona została uwaga ogólna. Informacja o śmierci zawsze przedstawiana jest $\mathrm{w}$ trzeciej osobie. Nigdy nie będzie występować we własnym opowiadaniu życia, nie będzie dotyczyć podmiotu opowieści.

Śmierć osób bliskich może pojawić się w snach. Napięcie uczuciowe, myśli o bliskich, którzy znajdują się w niebezpieczeństwie, chorują, są na wojnie, daleko, może śnić się, wyśnić się osobie, która je kocha. Szwajcarska badaczka Catherine Schmütz-Brun opowiada o nagłej śmierci pisarza w bibliotece, gdy czytał swoją książkę na temat markiza de Sade.

Sny o zmarłych pojawiają się w opowieściach rodzinnych. Są osoby, które wierzą w prawdziwość snu i opowiadają, co się im śniło. Niektóre opowieści senne realizują się w rzeczywistości. Opowieści te są powtarzane i upatruje się w nich potwierdzenia prawdziwości snów. Są osoby przekonane o swoich zdolnościach proroczych, że mogą wyśnić chorobę lub nieszczęście czy śmierć bliskich. Nie przekonuje ich przysłowie: Sen mara, Bóg wiara. Śnić o czyjejś śmierci, wyśnić śmierć to przeżycie traumatyczne, głęboko raniące nas, wywołujące niepokój i lęk, traumę.

Z rozważanym tematem śmierci i biografii wiążą się nekrologi. Notatki informujące o zgonie, pogrzebie osób bliskich, znanych, znaczących, ukazują się przed pogrzebem lub po pogrzebie. Nekrologi zawierają informacje biograficzne, daty urodzenia, zawód, pełnione funkcje społeczne, role społeczne w rodzinie i środowisku, a także informacje o czasie i miejscu pogrzebu, o woli zmarkego i rodziny, np. o nieskładaniu kondolencji, o nieprzynoszeniu kwiatów, o datkach na rzecz instytucji charytatywnej lub opiekuńczej. Na przykład aktor Adam Hanuszkiewicz prosił o datki na rzecz Skolimowa, Domu Opieki dla Aktorów. Za zebrane pieniądze wyremontowano jedną $\mathrm{z}$ łazienek. 
Od nekrologów łatwo przejść do obrzędów pogrzebowych w kręgu kultury europejskiej, do zwyczajów związanych z żałobą - z czarnymi ubraniami, z obrzędem zakupu trumny, ubiorem do trumny, nabożeństwem przy zwłokach, otwartej czy zamkniętej trumnie. Ciekawe jest opowiadanie młodego człowieka, Szwajcara, który poszukiwał pracy i zatrudnił się w przedsiębiorstwie pogrzebowym. Przeszedł szkolenie dotyczące przygotowania zwłok do pogrzebu. Początkowo każdy kontakt z osobą zmarłą bardzo przeżywał, ale z czasem przyzwyczaił się i uważał, że jego praca jest zwykłą pracą.

Herve Beeton analizuje swoją podróż do Indii, gdzie pojechał po ukończeniu studiów. Indie, ich klimat, krajobrazy, stosunki społeczne wymagały spokoju i czasu, aby je rozumieć i pojąć. Głębokim przeżyciem był pobyt nad rzeką Ganges, gdzie odbywa się palenie zwłok zmarłych. Płonące stosy, płacz rodziny, unoszący się dym, a potem wrzucanie prochów do rzeki stanowiły przeżycie trudne, traumatyczne. Śmierć i żałoba rodziny przyczyniły się do innego stosunku do śmierci, do obrzędów. Był głęboko wstrząśnięty tym zwyczajem.

Bardzo osobiste przeżycia zawiera opowieść o śmierci siostry Daniel Renault. Jej siostra była chora od dzieciństwa i nosiła w sobie śmierć, ale nauczyła się żyć z chorobą, Była bardzo związana uczuciowo ze straszą siostrą. Bywała u niej, była chrzestną matką jej dzieci. Razem jeździły na urlopy, razem spędzały święta, chodziły na zakupy. Jej śmierć, choć spodziewana, stanowiła traumatyczne przeżycie. Starsza siostra - autorka, umieściła dużo fotografii w domu. Jedne stały na nocnym stoliku, tak że przed snem patrzyła na nią i rano po przebudzeniu znowu na nią patrzyła. Jednak ani na cmentarzu, ani w obecności fotografii i przedmiotów siostry nie czuła jej obecności, bliskości. Bliskość przynosiła modlitwa i pobyt w Kościele.

Kolejna narracja dotyczy przeżycia katastrofy samolotowej. Joanna była jedną z pasażerek, miała świadomość katastrofy, rychłej śmierci. Pojawił się ogień w samolocie, ale służby porządkowe utrzymywały spokój i opiekowały się pasażerami. Narratorka była ciężko ranna, ale nie straciła świadomości. Długo leczyła się. Postanowiła wykorzystać zaangażowanie się w pracę z osobami zagrożonymi śmiercią w realizacji własnego projektu. Ukończyła dodatkowe studia i podjęła pracę w placówce opieki nad osobami śmiertelnie chorymi.

Kolejna narracja dotyczy nagłej śmierci młodej dziewczyny, która pojechała na wakacje do Tajlandii i zginęła w trakcie tsunami. Jej koleżanka nie mogła pogodzić się z tą śmiercią. W szkole, gdy była na egzaminie, profesor zapytał się, dlaczego nie ma jej koleżanki obok niej. Bardzo przeżyła to pytanie. Żyła pogrążona w żałobie, chciała zorganizować uroczystość, swoisty pogrzeb ofiar tsunami. Dowiedziała się, że po II wojnie światowej zorganizowano uroczystość w jednym z liceów w Paryżu ku czci koleżanek, które zginęły w czasie II wojny. Żałobną uroczystość udało się zorganizować także w jej szkole. Przeżywanie żałoby stało się lżejsze, choć trwało. Przeżycie to wpłynęło na wybór kierunku studiów, były to studia psychologiczne połączone $\mathrm{z}$ kinematografią. 
Dwudziesty pierwszy wiek chce zapomnieć grozę śmierci dwudziestego wieku. Uratowani więźniowie z obozów śmierci nie chcą powracać do wspomnień głodu, zimna, bólu, strachu, nocy bez snu i wstawania w nocy na apele. To było, ale chce się to ukryć w ciszy i spokoju.

Trudne sprawy poruszył artykuł poświęcony Ruchowi Czwartego Świata, którego organizatorem był ksiądz Józef Wrzesiński. Sam wywodził się z bardzo biednej rodziny i całe życie poświęcił posługiwaniu ludziom najbiedniejszym, wykluczonym, marginalizowanym. Założone przez niego stowarzyszenie, wspólnota miała na celu wyzwolenie w rodzinach najbiedniejszych chęci wyjścia z biedy, szukania sposobów polepszenia swojej egzystencji, czynienia małych kroków w polepszaniu życia. Te małe kroki to alfabetyzacja, porządek, samorządność, praca, jak naprawy, sprzątanie, segregacja śmieci i tym podobne. Stowarzyszenie stało się ruchem światowym, miało swoje struktury, ale jego duszą, siłą i głównym organizatorem był Józef Wrzesiński, po jego śmierci Ruch się załamał. Artykuł analizuje sytuację żałoby osobistej działaczy, wolontariuszy i zbiorowej wspólnoty. Analizowano wierność idei zmarłego Twórcy ruchu. Ile zostało z wartości i drogi, jaką wytyczył, czy śmierć załamała przekaz wartości, czy po śmierci jeszcze kontynuuje się tradycję służby najbiedniejszym. Śmierć dotyczy funkcjonowania autorytetu i wartości zmarłej osoby w okresie żałoby i po żałobie.

Ruch przeszedł kryzys, ale się otrząsnął. Stwierdzono, że już nigdy nie będzie tak jak było, ale można być wiernym ideałom Ruchu i pamięci założyciela, realizować misję Ruchu Czwartego Świata.

Ostatnie artykuły poświęcone są cmentarzom, pomnikom na cmentarzach $\mathrm{i}$ tablicom pamiątkowym, które $\mathrm{z}$ biegiem lat tracą aktualność.

Treść relacjonowanej książki Historia śmierci w biegu życia w pełni odpowiada tytułowi. Rzeczywiście śmierć została ukazana w różnych aspektach. Opisują ją osoby profesjonalnie związane z procesem umierania, wspierające chorych w fazie agonalnej. Mówią o wkraczaniu w próg śmierci. Mówią osoby po ciężkich wypadkach, w trakcie rehabilitacji i życiu po życiu normalnym, samodzielnym. Mówią osoby dotknięte żałobą po nagłej śmierci przyjaciół, krewnych, osób bliskich, ważnych. Mówią osoby związane z obrzędami pogrzebu lub obserwujące pogrzeby, w tym obrzędy palenia zwłok w Indiach. Mamy relacje z odwiedzin cmentarzy i miejsc poświęconych zmarłym przez tablice pamięci.

Każda relacja wywołuje wspomnienia, zmusza do refleksji. Ważne są wskazania metodologiczne - o śmierci pisze się zawsze w trzeciej osobie, nigdy nie występuje w pierwszej osobie, o naszej śmierci mogą napisać inni. Dlatego śmierć w badaniach biograficznych może wystąpić jako myśl o sobie w perspektywie czasu przyszłego, testamentu, obrzędu. Tak wszechstronna praca mogła powstać tylko w oparciu o duży zespół badaczy, autorów. Autorzy wywodzą się z kilku środowisk, z Uniwersytetów z Nantes i Tours we Francji i Uniwersytetu w Montrealu w Kanadzie oraz Szwajcarii. 
Inspiratorkami książki są główni redaktorzy i badacze - profesor Martine Lani-Bayle, Gaston Pineau i Catherine Schmütz, najmniej mi znana osoba z Szwajcarii, z Uniwersytetu we Fryburgu. Książka zawiera informacje o kształceniu służb paliatywnych, o ruchu na rzecz opieki nad chorymi termalnie.

\section{Literatura}

Baczak J.,1995, Zapiski z nocnych dyżurów, Społeczny Instytut Wydawniczy Znak, Kraków. Olaizola J. L., 2012, Jan od Krzyża, Wydawnictwo eSPe, Kraków.

Pineau G., Lani-Bayle M., Schmütz C., 2012, Histoire de morts au cours la vie, Harmattan, Paris. Sieck A., 2012, Mistyczki, Wydawnictwo eSPe, Kraków.

Bauby J., 2007, Skafander i motyl, Słowo Obraz Terytoria, Gdańsk.

Humbert V., 2002, Je vous demande le droit de mourir, Paris. 